\title{
The Impact of Privatization on the Management Process/Case Study
}

\author{
Mile Mirchevski \\ Information Technology/Faculty of Technical Sciences, International Balkan \\ University, Skopje, Republic of Macedonia
}

Tel: 389-7020-0312 E-mail: Mile.Mircevski@t-home.mk

Received: October 12, 2012 Accepted: October 29, 2012 Published: December 31, 2012

doi:10.5296/bms.v3i2.2506 URL: http://dx.doi.org/10.5296/bms.v3i2.2506

\begin{abstract}
In this document, the process of business management in the biggest telecom operator in Macedonia, was considered, taking in mind two periods of company's evolution: the period before and the period after its privatization. The world of business is undergoing radical change. The rapid development of information technology, especially the Internet and web based technologies, enables managers to design and create new organizations and new organizational structures. A key function in the business management process for managers should be to define and to identify the common vision and later on to insist on aligning the individual goals and the company's goals within that vision.

The process of globalization, supported by rapid IT usage is recognized and present in almost all business areas all over the world. The telecom industry is one of the most influenced. The telecom company in Macedonia ("The Company"), which is the scope of this study, was one of those examples. Considering all these facts, several topics that characterized the company before and after the process of its privatization were considered in this document: Management approach, Organizational topics, Employees and HR issues.
\end{abstract}

Keywords: HR issues, Managers, Management process, Organization, Privatization, Rebranding 


\section{Introduction}

The adjustments of the organizations toward the new challenges have been, and will be, the challenge for the managers. In order to be more efficient, to use their resources more effectively, to be in a position to adjust themselves to the frequent changes of the external environment, and finally, to be in a position to satisfy customer's requirements, the companies have to be ready to leave the traditional hierarchical organization and to transform themselves to the new more flexible organizational structures, transforming in parallel their business management. Organizing, as one of the management functions : planning, organizing, coordination, motivation, controlling (Schuklev, 2009), has and will have, an important role in the management process. The traditional hierarchical organizations which fail to redesign themselves in the next period, is likely to disappear. One of the most important factors which influence the most frequent changes in the environment is the fast development of Information and communication technology (ICT), especially the Internet and web based technologies, called ICT Revolution. If the steam engine, as a new form of power, created an Industrial revolution in the nineteenth century, information technology (IT), especially the Internet, created a technology revolution in the last half of the twentieth century.

The new trends in marketing and sales, supported by ICT, have created a new frame for doing business. This is a new world of e-business, transforming company's organizational structures, adjusting business models and business management, in order companies to be in a position to answer to the challenges and to the new capabilities of the market.

In parallel with the world's business trends, the organizations in Macedonia were facing the same challenges, to survive in the frequently changing environment. As a result of the globalization, "The Company" became a part of Deutsche Telekom AG family. The company had to adjust its business model, its business management model, its strategy and organizational structure on the group level.

Considering all these facts, to manage IT in this "Company" for many years and being a witness of a lot of activities that happened in the company before and after its privatization, was the biggest challenge for the author of this article, in his managerial career.

\section{About the Company}

"The Company" is a telecommunications provider in the Republic of Macedonia, with headquarters in Skopje. It is a part of the Magyar Telekom Group, which is a fully consolidated subsidiary of international Deutsche Telekom Group. "The Company" is the dominant mobile and fixed line operator on Macedonian market. It also operates as an internet service provider, and as an integrated telecommunications and entertainment services provider.

The company has been present on both the top-most successful companies list and on the top-largest companies list, and has been ranked among the top 10 companies in the Republic of Macedonia. 
3. The History of the Company

The history of the Company can be divided in four phases. All of them will be explained in short, putting the focus on several topics which characterized all of the phases:

1) Management approach,

2) Organizational topics,

3) The employees and HR issues.

All these topics were developed over time and were depended on the internal company's environment and on the external environmental factors in the country. The policy was among the most influential ones. The author of this article was an active participant in all of the phases of the Company history, on different managerial levels, starting as an application developer in the Billing department, ending as an IT Director. As a witness, managing IT resources, the author was in a position to observe the company's evolution during different periods of time and to compare its organizational structures and especially the differences in business management. Being in a position to practice management in both periods, before and after the privatization, the author was in a position to observe different management strategies, different styles of management, and different styles of leadership. As the time was passing, some virtual components, supported by radical IT development, started to became a reality in the company, initiating the general management to take place too.

One of the few authors who have made an attempt to explain the role of the general manager was the French management theorist Henry Fayol, known as a founder of the functional management. He, in 1917 set out five basic functions, which are the main responsibilities of the managers, known as PpOKKK (Planning and prediction, organizing, commanding, coordinating and controlling). Later on, in the 1930 s, several management scientists divided management into seven separate tasks, known by the acronym POSDCORB (Warner \& Witzel, 2004a):

- $\quad$ Planning - deciding where the organization will go;

- Organizing - how to ensure the best possible fit between the structure of the business and its goals;

- Staffing - first, the right people in the right jobs and second that people's full potential is available to the organization;

- Direction - enabling employees to understand more clearly what the organization needs of them, what their own place in the organization is and how best they can carry out their own tasks,

- Coordination - providing things to be done without compelling or ordering people to do them, but rather by harmonizing efforts to that everyone is pulling willingly towards the same goal,

- $\quad$ Reporting - gathering and dissemination of information and knowledge; 
- $\quad$ Budgeting - the allocation of funds to be spent on particular projects, calculating the potential return on each and then managing finances so that those returns are achieved.

No matter that in a mean time a lot of definitions about the managerial functions were developed, it was a fact that almost all above mentioned managerial functions were parts of managing "The Company".

\subsection{The Period of Company's Growth.}

The first phase includes the period between the establishment of the company in 1940, until 1993 (Kostovski, 1998).

1) Management approach - was characterized with a lot of enthusiasm, not real management from the very beginning. The formal managerial hierarchical structure evolves over time, adding additional managerial levels, becoming more complex. During the first years of this phase, the role of the top managers was the most emphasized. The most important managerial functions for the top managers were: planning, organizing, and coordinating. During this period of time controlling and motivating are less important. The external environment is highly dynamic and as a result, the role of the top managers is crucial. The leadership is becoming more visible. There is a lack of expertise and knowledge about the management and its role.

The role of the middle management in the first years of this period is minor. This is a consequence of the absence of knowledge and experience and not having an adequate human resources policy. The management on the lower levels consists of managers with a low level of knowledge about the managerial functions but also with inadequate education. The shortage of knowledge and skills is compensated with a lot of enthusiasm, energy, excellent interpersonal relations, motivation and a good will to help.

2) Organizational topics - the organizational structure is rigid, formal, and hierarchical, with narrow span of control, evolving over time, adding additional hierarchical organizational levels.

3) The employees and HR issues - the employees are without training, lacking knowledge. Good interpersonal relations were characteristics for this period of time - the motto was "To be one family". The compensation and the motivation of people were on high level.

\subsection{The Period of Preparing the Company for Separation}

The second phase covers the period from 1993 until 1997, when the separation of the company in two legal public entities: Postal operations and Telecommunications and Telegraphy, happened.

In 1995, the company became an Internet services provider and the Mobile services were introduced too."The Company"was introduced on $1^{\text {st }}$ of January 1997 as a state-owned company independent of the Postal office.

1) Management approach - the changes in the highest managerial positions including CEOs, are very frequent, influenced by the political situation in the country. The middle management strengthened, which resulted in a better communication between the top and the middle management. 
2) Organizational topics - the company is still keeping the old rigid hierarchical organizational architecture.

3) 3. The employees and HR issues - the employee were put on a big pressure because of the separation of the company. The question: "What will happen with me, and where will I belong?" was very frequent.

\subsection{The Period of Preparing the Company for Privatization}

The third phase covers the period from 1997 - 2000 - preparation of the company for privatization. In March 1998, the company was registered as a Joint Stock Company in public ownership in order to prepare for privatization and for working in the competitive environment.

1) Management approach - strengthening the middle management role continue. The middle managers became the real link between the top managers and the lower level managers. Organizing, coordinating and internal departmental planning were the most important middle manager's functions.

2) Organizational topics - during this period of preparation, some essential organizational changes happened. The customer came in the focus of company's interest. Still, the organization was structured by functions. This organization could experience significant sub optimization (Pearlson \& Saunders, 2006a):

- The information prepared by other department may be recreated,

- Communication gaps between departments are often wide,

- Creating a complex and frustrating bureaucracy,

- Handoffs between silos are often a source of problems,

- Silos tend to lose sight of the objective of the overall organization goal and operate in way that maximizes their local goal. As a result, the "big picture" is lost.

The new organization, presented in Figure 1, was customer oriented, with the customer in the centre. 


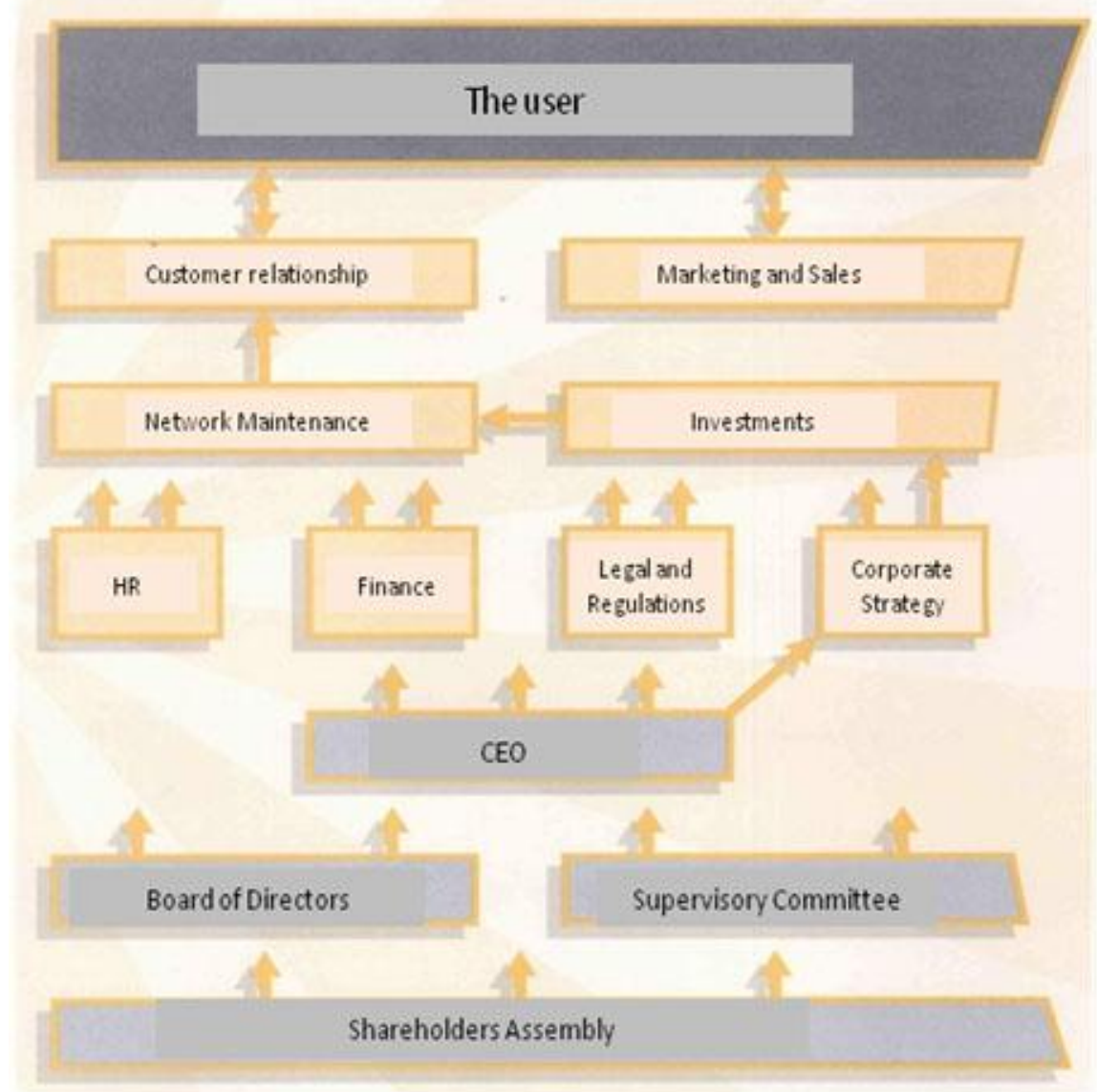

Figure 1. Organizational Structure of "The Company", 1998

Source: Annual Report, “The Company” 1998, p.15

The organizational structure is much flatter, with less hierarchical levels but a larger span of control.

The centralization of the activities is the main characteristic in this period (The Company, Annual Report, 1998).

3) The employees and HR issues - new profile of employees needed. New departments for customer relationship and marketing and sales were established. The focus started to move from technical people to those ones dealing with the customer. Marketing and Sales employees were recognized as the most valuable human resources in the company.

\subsection{The Period of Privatization and After Privatization}

The fourth phase begins from Year 2001, when the Company was privatized. This is the most challenging period of the company evolution. When considering all the topics discussed previously, it was obvious that a new strategy will take place, the monopoly of the company will end and working in a competitive environment will become a reality. As a result, a lot of different additional activities will be added with the privatization: new business models, new products will be offered to the customers, new IT systems will be 
implemented, new organizational structure with a new units will be implemented, new way of management will be introduced and managers with new styles will lead the company.

\subsubsection{The Privatization}

The privatization of the company took place in January 2001, when the Government of the Republic of Macedonia and a consortium led by the Hungarian telecommunications provider Matav, signed a contract for the acquisition of "The Company's" shares, whereby Matav entered the shareholders register as the owner of $51 \%$ of the shares and thus became the dominant owner of the company. As of October 2008, the Macedonian Government still holds a stake in company stock directly.

On 1st of June 2001, a mobile phone provider began functioning as a separate legal entity (Daughter Company).

1. Management approach - the complexity of managing in the new environment required additional new managerial skills to be added to the original model. The four new tasks were: Communication, Assessment, Learning and Valuation, known by the acronym CALV (Warner \& Witzel, 2004b):

- Communication - to ensure that knowledge flows are efficient and timely, linking all the elements of an organization to each other and to suppliers and customers;

- Assessment - matching of the organization's goals with its form and structure on a dynamic basis, and altering or amending that structure when opportunities arise;

- Learning - the consistent replenishment of an organization's stock of knowledge capital through such activates as training and education, R\&D etc.

- Valuation - continuous and dynamic reassessment of knowledge assets in terms of their present and future value to the firm.

With the privatization of the company, the new owners, Matav and Deutsche Telekom AG, started to delegate their representatives in the top management, initiating with this a need for harmonization of company's strategy, policy and procedures with those in their companies. In 2004, under the project called "Road to Success (R2S)", a new concept was implemented, characterized with:

- Redefinition and harmonization of future company vision,

- Process orientation, with the customer's and the market's needs in the focus,

- Increasing the satisfaction of the stakeholders (Customers, Employees and Shareholders),

- Improving the efficiency and the competitiveness,

- Building corporate culture under Deutsche Telecom.

Expected benefits were: 
- Customer satisfaction,

- Employees satisfaction,

- Shareholders satisfactions,

- Stable financial results.

- Continuous services, products and processes development

In this period of time, for the first time IT was treated on the proper manner and a lot of crucial corporate IT systems were implemented: a new Information System and Technology Strategy was developed, a new corporate computer network Core, Wide Area Network - WAN, Metropolitan Area network - MAN and Local Area Network-LAN, Billing system, Enterprise resource planning system (ERP) - SAP, Call Centre, several IT Security systems were implemented.

\subsubsection{Rebranding}

In 2007, Deutsche Telecom AG started the process of rebranding. "The Company" as all other Deutsche Telecom subsidiaries, became a part of this process. On May 1, 2008, "The Company" officially became part of Deutsche Telekom global family, accepting the new "T" brand as an umbrella of the two sub-brands T-Home and T-Mobile. With the process of rebranding, not only company's logo was changed, but also company's business processes, policies and procedures were harmonized on a group level. The main goals of rebranding were:

- The presence of the company on the market to be recognized as a unique and transparent,

- The new brand architecture to be in relation with customer's needs,

- The brand identity is focused towards customers,

- Positioning of the corporate T-brand as a common one, for fixed - T-Home and mobile T-Mobile services (The Company, Internal Informant, 2008).

2. Organizational topics - a new organizational structure, in line with the "Fourth pillars" organizational structure of Deutsche Telekom AG, shown on Figure 2" was introduced. Business units are organizational wholes, where the tree processes: providing excellent services, customer care and marketing and sales were bundled in one businesstechnological system.

In 2004, as a result of the corporate project Road to success (R2S), a new organization based on the concept of "unique service supply management" with tree centralized functional areas was implemented. The concept of the new organization was built on several principals: 
Shareholders

Assembly

Board of

Directors

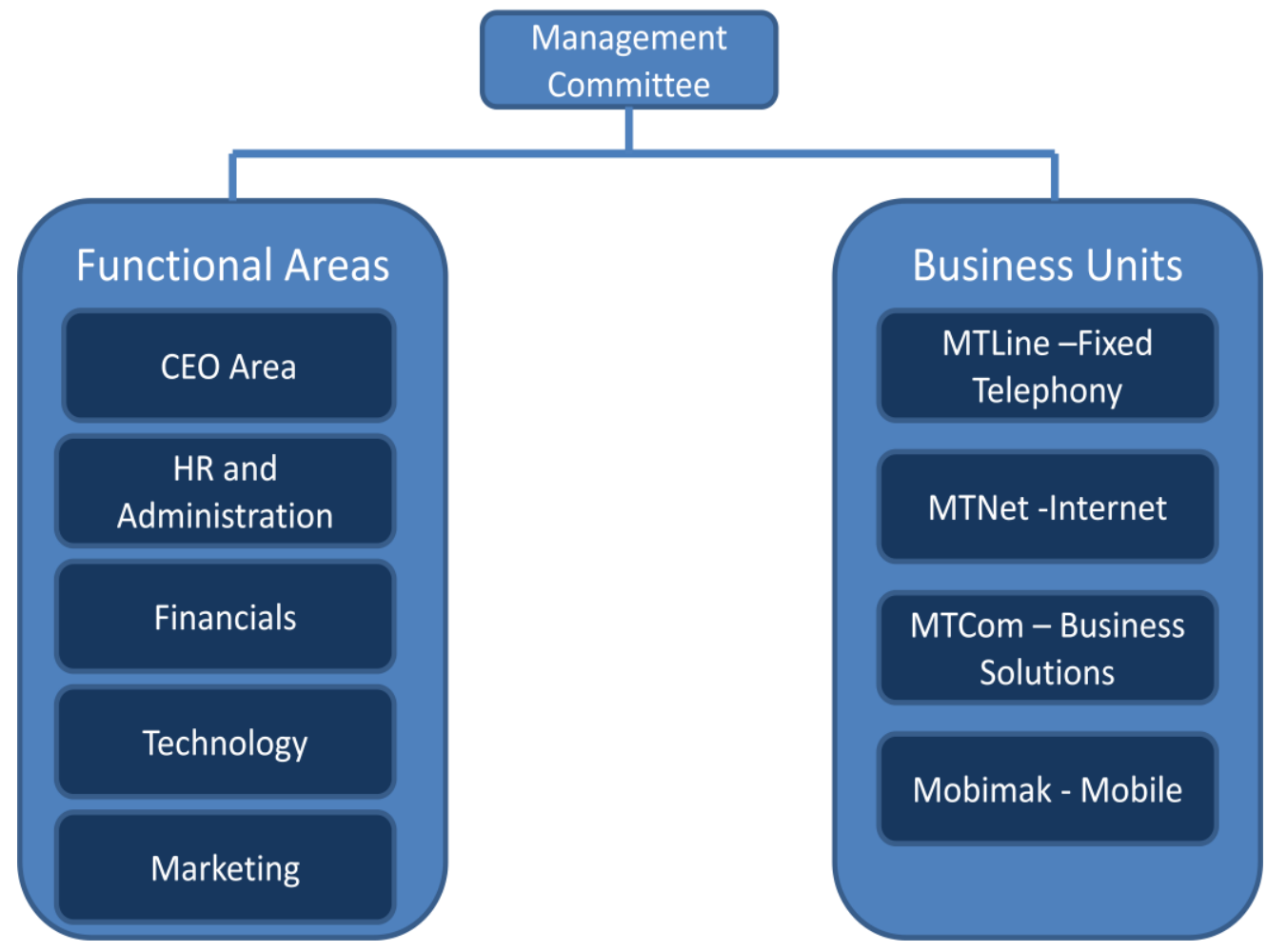

Figure 2. Organizational structure, "The Company", 2001

Source: Annual Report, "The Company” 2004, p. 25

- Centralization,

- Decreasing the number of hierarchical levels and organizational units,

- Strengthening the communication relations among the internal company units.

The three implemented centralized functional areas were:

- Strategic/Central Area - covers the functions which are of strategic importance for the company,

- Area for crating revenue (Marketing and Sales) and

- Area for supporting the business (Technical area, Financial area and HR area).

In regards with the organization, it is worthy to be mentioned that for the first time

Corporate Projects (SAP, Billing and Call Centre) as separate organizational units were introduced, engaging corporate resources from all over the company, even creating virtual teams for some purposes. 
3. The employees and HR issues - new training plans were developed, with a focus on Marketing and Sales. New knowledge and new skills acquired. Before the privatization, "The Company" was a state owned company with a full monopoly and no competition. The behavior of people was different, with stable job positions. After privatization, the Government was pushed to change the legislative and to liberalize the telecom market. After the new competitors, the Greek's Cosmofon and the Austrian VIP started to operate, the market situation become totally different. The pressure under the employees became stronger and persistent. Several HR issues have been raised:

- Pressure to decrease the number of jobs (still actual),

- Pressure for early retirement,

- Pressure for changing the job position and to accept the new one,

- Pressure for bigger revenue and bigger EBITTDA

- $\quad$ Pressure to achieve some not realistic deadlines (Mirchevski, 2011).

4. About the project methodology - the project for privatization has finished successfully. New presentation skills and techniques were acquired. Considering PMI methodology, the author as company's representative was involved in:

- Executing Process Group (Acquire, Manage Project team - Project HR Management Area, Distribute information, Manage Stakeholder expectation - Project Communication Management Area) and

- Monitoring and Controlling process group (Control schedule - Project Time Management Area, Report performance - Project Communication Management Area).

\section{Comparison: "The Company" before and after Privatization}

The period before privatization was totally different in all aspects of company's behavior. After privatization came, there were different rules in place, influencing all business areas. New Business strategy was implemented, predefining the vision of the company, giving a direction where a business seeks to go and how it expects to get there. The top management started to harmonize the company's strategy according to the market forces, customer demands, and organizational capabilities. Market forces created the competitive situation for doing business. Customer demands comprise the needs of the individuals and companies who purchase the products and services available on the market. Organizational capabilities include the skills and experience, showing how strong the company is. A new business model was developed. Organizational strategy includes the organization's design and the choices it makes to define, set up, coordinate and control its work processes (Pearlson \& Saunders, 2006b).The organizational strategy is a plan that should answer the question about how will be the company organized in order to achieve its goals and implement its business strategy. IT strategy was supporting both of these strategies. The management of the company was trying to adjust all the strategies in order to adjust the company in the new environment.

The conclusions of comparing the periods before and after privatization, taking in 
consideration the Management approach, the Organizational topics and HR issues, are listed below in the Table 1 .

Something that is relevant for both periods, before and after the privatization, is the influence of Information technology. In the monopoly, it's just a tool to improve the quality of the service or the product, but in a competitive environment it's a sophisticated tool that helps in all business areas to develop, to grow, to maintain the business and to satisfy market requirements. Information system strategy always has an

Table 1. Comparison: "The Company" before and after privatization

\begin{tabular}{|c|c|c|c|}
\hline & Before privatization & After privatization & Remarks \\
\hline General Facts & $\begin{array}{l}\text { Full monopoly } \\
\text { No competition } \\
\text { Stable job positions }\end{array}$ & $\begin{array}{l}\text { The Government pushed to } \\
\text { change the legislative to } \\
\text { liberalize the telecom market. } \\
\text { New competitors, the Greek's } \\
\text { Cosmofon and the Austrian } \\
\text { VIP started to operate }\end{array}$ & \\
\hline $\begin{array}{l}\text { 1.Management } \\
\text { approach }\end{array}$ & $\begin{array}{l}\text { No Real management } \\
\text { A lot of enthusiasm and } \\
\text { very good interpersonal } \\
\text { relations } \\
\text { The formal managerial } \\
\text { hierarchical architecture, } \\
\text { adding new managerial } \\
\text { levels } \\
\text { Leadership in several areas } \\
\text { emphasized }\end{array}$ & $\begin{array}{l}\text { MT and DT experience } \\
\text { transferred, } \\
\text { More professionalism, } \\
\text { supported by new knowledge, } \\
\text { New methodologies, } \\
\text { policies, procedures, ideas in } \\
\text { place, } \\
\text { New IT systems delivered, } \\
\text { Different management styles } \\
\text { promoted }\end{array}$ & $\begin{array}{l}\text { The } \\
\text { Leadership } \\
\text { strongly } \\
\text { promoted and } \\
\text { recommended } \\
\text { in theory, but } \\
\text { doesn't work } \\
\text { in practice. }\end{array}$ \\
\hline $\begin{array}{l}\text { 2. Organizatio- } \\
\text { nal topics }\end{array}$ & $\begin{array}{l}\text { The organizational structure } \\
\text { rigid, formal and } \\
\text { hierarchical, with a narrow } \\
\text { span of control, adding } \\
\text { additional hierarchical } \\
\text { organizational levels over } \\
\text { time } \\
\text { Some organizational units } \\
\text { artificially added }\end{array}$ & $\begin{array}{l}\text { Organizational structure } \\
\text { much flatter, with less } \\
\text { hierarchical levels with larger } \\
\text { span of control } \\
\text { Customer oriented, } \\
\text { More frequently virtual teams } \\
\text { and virtual organizational } \\
\text { unites in place. }\end{array}$ & \\
\hline $\begin{array}{l}\text { 3.Employees } \\
\text { and HR issues }\end{array}$ & $\begin{array}{l}\text { Lack of trainings and skills, } \\
\text { Good interpersonal } \\
\text { relations, } \\
\text { A lot of enthusiasm, } \\
\text { The compensation and the } \\
\text { motivation of the people on } \\
\text { a high level }\end{array}$ & $\begin{array}{l}\text { More trainings offered, } \\
\text { More knowledge acquired, } \\
\text { Experience exchanged, } \\
\text { Employees under pressure, } \\
\text { worrying about their jobs, } \\
\text { No real compensation models } \\
\text { in practice, } \\
\text { Theoretical performance } \\
\text { evaluation of the employees } \\
\text { (by the book) }\end{array}$ & $\begin{array}{l}\text { HR, the } \\
\text { weakest part, } \\
\text { DT's } \\
\text { suggestions in } \\
\text { theory, but } \\
\text { doesn't } \\
\text { implemented } \\
\text { in practice. }\end{array}$ \\
\hline $\begin{array}{l}\text { 4.Project } \\
\text { management }\end{array}$ & $\begin{array}{l}\text { No professional } \\
\text { methodologies used. }\end{array}$ & $\begin{array}{l}\text { Magyar Telecom and } \\
\text { Deutsche Telecom experience } \\
\text { transferred. New } \\
\text { methodologies introduced. } \\
\text { For some global projects } \\
\text { virtual management with } \\
\text { virtual teams used. }\end{array}$ & \\
\hline
\end{tabular}


influence, intended or not, on organizational and business strategy including the business management.

In order to identify the impact of IT on business efficiency in the company, author of this article, conducted a survey in "The Company". Some of results are presented in this paper.

The research encompasses the answer on the question: "How much IT (in form of electronic communication and collaboration - usage of e-mail, Internet, messenger, portals

etc.), influences business efficiency of the company?". The result of the survey, presented on Figure 3, has shown that, most of the respondents have responded that the influence is the highest and high.

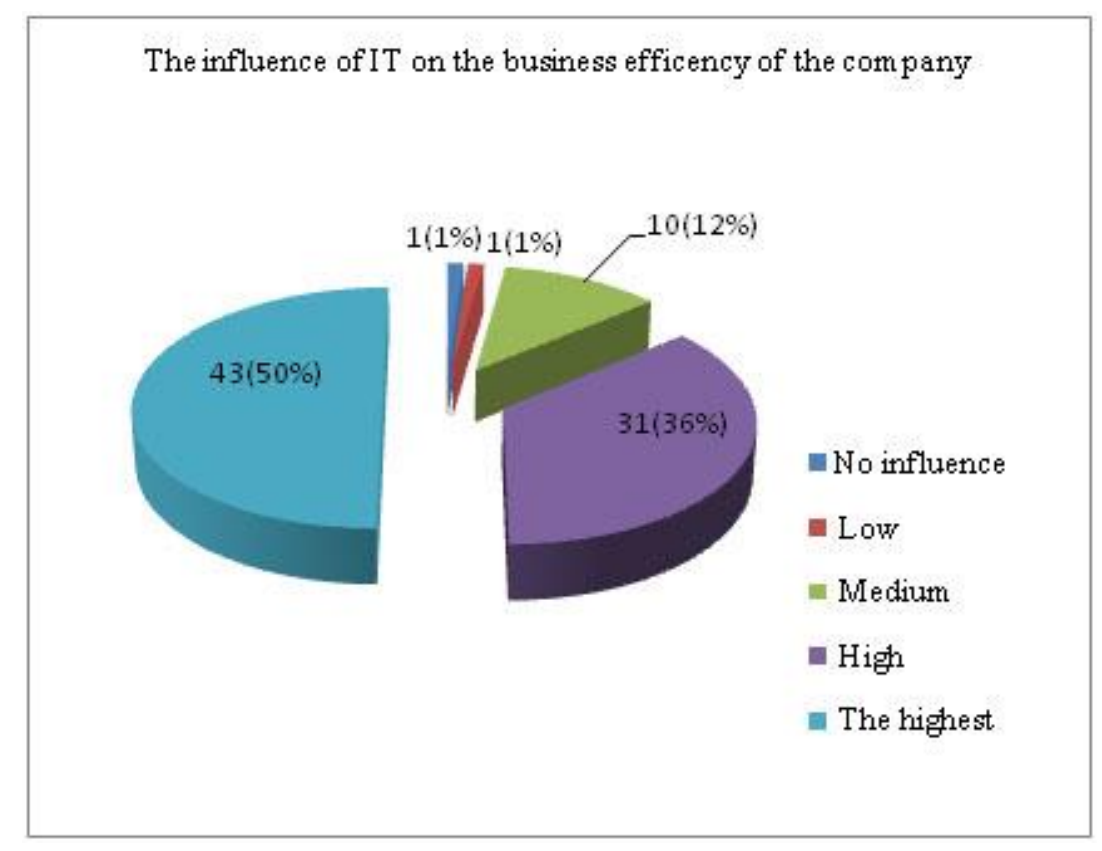

Figure 3. Analysis of answers: The influence of IT on the business efficiency of the company

Source: Mirchevski, M.,(2011). PhD Thesis "Managing in Virtual Organizations", Skopje, Macedonia: Ss. Cyril and Methodius University in Skopje, Macedonia, Faculty of Economy-Management, pp 266,

The results proved that the employees are looking at IT not only like a tool to help them in their daily activities but also like a tool to improve company efficiency, effectiveness, management, in short, to improve business.

\section{Conclusion}

Managing in competitive environment is totally different than managing in monopoly. There are a lot of factors influencing company's behavior when working in competitive environment, but the strongest are markets needs and customer requirements. Information and Communication Technology (ICT) is the most substantial factor in supporting companies in the competitive environment. The companies are becoming more and more 
dependent on ICT and information systems and if they would like to survive in today's frequently changing environment, they have no other choice than extensive usage of ICT. ICT in general and the Internet as a driving force in particular, are facilitating profound changes in the structure of today's business, transforming the economy and the society.

Not only the technology is influencing the business model, the organizational structure, the way of managing the organizations, but also the world's business trends as the globalization is, are playing an essential role in this.

The new rules for market liberalization, are recommending state owned companies to be privatized and to be leaved on the open competitive market. Sometimes these transitions are not going so smoothly and in a lot of cases, the companies are facing a lot of problems. This is particularly important with the Human Resources, which are not previously prepared for the changes that will come. Management should carefully plan all necessary steps if they would like to be successful in managing these changes.

Managing with the companies in today's environment is perhaps the most challenging job, and mangers should always have in mind that people are the most valuable company's assets, which unfortunately, is not always a case in practice.

\section{References}

Kostovski, R. (1998). Macedonian Post, Macedonian Telecomunications. Skopje, Macedonia: Mi-An, pp 114- 206. (The original: Костовски Ристо: "Македонска Пошта, Македонски Телекомуникации “),

Mirchevski, M. (2011). PhD Thesis: Managing in Virtual Organnizations. Skopje, Macedonia: Ss. Cyril and Methodius University in Skopje, Macedonia, Faculty of Economy-Management. pp. 236-261,

Pearlson, K. E., \& Saunders, C. S. (2006a). Managing \& Using Information Systems - a strategic approach. New York: John Wiley \& Sons, Inc. pp.111-112

Pearlson, K. E., \& Saunders, C. S. (2006b). Managing \& Using Information Systems - a strategic approach. New York: John Wiley \& Sons, Inc. p.21.

Schuklev, B. (2009). Management. (6 ${ }^{\text {th }}$ ed.), Skopje, Macedonia: Ekonomski Fakultet, p.63.

Telekom, The Company - internal informant. (2008). Skopje, Macedonia.

The Company - Annual Report. (1998). Skopje, Macedonia, pp. 12-13.

Warner, M., \& Witzel, M. (2004a). Managing in Virtual Organization. London: Thomson Learning. p. 108,

Warner, M., \& Witzel, M. (2004b). Managing in Virtual Organization. London: Thomson Learning. p. 111. 